Article

\title{
Do International Capabilities and Resources Configure Firm's Sustainable Competitive Performance? Research within Pakistani SMEs
}

\author{
Ma Degong ${ }^{1}$, Farid Ullah ${ }^{1, *}$, Muhammad Sualeh Khattak ${ }^{2}$ and Muhammad Anwar ${ }^{3}$ (I) \\ 1 School of Economic, Sichuan University, Chengdu 610065, China; madg@scu.edu.cn \\ 2 Lecturer at Hamdard Institute of Management Sciences, Hadmard University Islamabad, \\ Islamabad 44000, Pakistan; Sualeh_ktk@yahoo.com \\ 3 Faculty of Management Sciences, International Islamic University Islamabad, Islamabad 44000, Pakistan; \\ m.anwar.ims@gmail.com \\ * Correspondence: faridtofan@ymail.com
}

Received: 27 October 2018; Accepted: 16 November 2018; Published: 20 November 2018

check for updates

\begin{abstract}
Market conditions in emerging economies are often reported as less stable and volatile. The business sector, especially Small and Medium Enterprises (SMEs) in emerging economies, face several shortcomings including lack of resources, lack of finance, lack of support and lack of human skills, etc. Hence, they look to international support and resources to survive in a long run in the dynamic markets. This research examines the role of international finance, international technology, international experience and international network in SME firms' Sustainable Competitive Performance (SCP) in Pakistan. SMEs are a major source of employment and value creation and, therefore, are very relevant to Pakistan economic and social development and improved sustainability. Hypotheses were tested on the data set collected from 304 emerging SMEs. After Structural Equation Modelling (SEM) was applied in Analysis of a Moment Structures (AMOS), the results indicate that international finance, international experience and international network significantly positively contribute to SCP, but international technology is not a significant predictor of SCP. This research recommends top managers and policy makers to give enough attention to the particular international resources and capabilities in order to configure their firm survival in the turbulent market.
\end{abstract}

Keywords: international finance; international technology; international experience; international networking; sustainable competitive performance; SMEs; Pakistan

\section{Introduction}

Globalization and the dynamic markets have dragged business enterprises into a race of achievement of sustainable competitive performance (SCP). Business organizations, regardless of their size and the nature of business, have given enough attention to invest in tangible and intangible resources to gain SCP [1]. In the last decade, a burgeoning literature has discussed the factors that significantly contribute to firm performance and success such as financial capabilities [2-4], networking [5,6], IT capabilities [7], innovation [8-10], business model innovation [11,12], intellectual capital $[13,14]$ and corporate social responsibility $[4,15]$, etc. in developed and emerging economies. However, Anwar and Shah [16] noted that firms in emerging economies face various problems such as lack of resources, lack of skills and lack of government support. Hence, they look to international support to enhance their performance. However, studies have discussed various external factors that can facilitate emerging firms (e.g., firms operating in emerging economies) to acquire valuable resources to improve their performance [17-19]. However, rare studies exist about the role of international 
capabilities and support in a host country business performance. Some international resources and capabilities (e.g., international technology and international finance, etc.) are very essential for a host firm to expand its operation. Surprisingly, it is unknown how international finance, international technology, international experience and international network facilitate SCP in a host country? This study fills the gap and answers the question "Do the international resources and capabilities (international finance, international technology, international experience and international networking) spur SCP?" To the best of our search and knowledge, none of the studies have tested the certain factors in this perspective. Hence, we claim novelty in terms of testing the international resources and capabilities toward SCP by collecting empirical evidence from Small and Medium Enterprises (SMEs) operating in an emerging economy. This research aims to recognize the most significant international resources and capabilities that can configure SCP in emerging markets. We test the model in the emerging market Pakistan that is located in the best trade route e.g., between Europe and Asia. The majority of the businesses are SMEs in the region. Moreover, it is claimed that SMEs in Pakistan face several challenges and do not receive adequate support by the government. Therefore, Pakistan SMEs often search for international resources and external support [16]. However, this study is not only limited to the emerging market in Pakistan. We also aim to disclose factors that are significantly important for developed and European firms where firms face a shortage of resources. Based on 304 Pakistani SMEs, this research clarifies and discovers the most prominent international resources that enable a host firm to survive in a long run. There is no single definition of SMEs worldwide. In Pakistan, SMEs are defined as "firms that have a number of employees less than 250 and the annual turnover is not higher than Rs. 800 million".

The role of international resources and capabilities in emerging markets cannot be underemphasized. Certain factors are not only important for the high performance of SMEs but also can save the newly established ventures from failure. For instance, it is claimed that more than $50 \%$ of SMEs fail in the initial stage due to the well-known reasons: lack of support, lack of resources and lack of capabilities [16]. Considering the high failure ratio, external resources (e.g., international resources) can play a significant role in long-term survival of SMEs. In addition, Estrin, Nielsen and Nielsen [20] argued that tangible and intangible resources are very crucial for the long run and internationalization process. However, firms have not all the required resources and capabilities to compete in a dynamic market. In this perspective, the support of international partners/ventures/banks can alleviate emerging firms to be sustained in the long run. Firms do not only need financial resources but also need modern technology, experienced managers and foreign relationships to go ahead and gain SCP.

This research makes theoretical contributions and suggests several practical implications for top managers and policy makers. For instance, Resource-Based View (RBV) indicates that a firm with unique resources and capabilities can build a sustainable competitive position in a turbulent market [21]. However, the international resources and capabilities such as international finance, international technology, international experience and international network are rarely discussed from the RBV perspective. Medcof [22] discussed international ties, technology and resources in the RBV context and scrutinized that international resources make managers more powerful in competing in a market. Similarly, Camisón and Villar-López [23] also demonstrated the role of international experience in the RBV context and argued that international experience can help firms to perform over others. In general, RBV describes that the valuable, rare and inimitable resources and capabilities help firms to gain a competitive advantage that, in turn, generates high profitability. In this view, the international resources and capabilities can stimulate a firm to make a sustainable competitive position in the industry that may not be achieved by the competitors. Social network theory asks how the firm network ties with external bodies configure its success and performance [24]. Based on the empirical evidence, this research assesses the theme of RBV and social network theory in terms of the international resources and capabilities, which are helpful for business organizations to achieve SCP. From the practical perspective, this research recognizes the prominent factors for emerging SMEs to enhance their survival through international resources and capabilities. We postulate that only 
international finance or technology do not stimulate SME performance in emerging markets, but the firms also need a relationship and experience of international markets to gain satisfactory performance. The international concept here means "any resource or capability offered by a foreign venture, bank or trader to a host firm". The concepts and definitions of the variables have discussed in Table 1.

Table 1. Concepts of the variables.

\begin{tabular}{|c|c|}
\hline Variables & Conceptualizations \\
\hline International Finance & $\begin{array}{l}\text { Finance available to host firms by foreign banks, foreign investors and } \\
\text { financial institutions. }\end{array}$ \\
\hline International Technology & $\begin{array}{l}\text { Foreign technology available to host firms for new product development, } \\
\text { delivery process and operation etc. }\end{array}$ \\
\hline International Experience & International dealing and trade experience of top management of the host firms \\
\hline International Network & $\begin{array}{l}\text { Relationship of the host firms with international customers, supplier and } \\
\text { businesses, etc. }\end{array}$ \\
\hline SCP & Superior performance in terms of products, services and sales revenue, etc. \\
\hline
\end{tabular}

This study is organized into five sections. In Section 1, we discussed the background, objectives, problem statement and contributions of the research. In Section 2, we stated literature review and the Section 3 is about methodology. In Section 4, we applied several statistical tests to analyze the data. Section 5 is the discussion chapter where implications have been stated. Section 6 provides the conclusions.

\section{Hypotheses Development}

\subsection{International Finance and Sustainable Competitive Performance}

The neoclassical theory demonstrates that financial integration can spur the growth of firms in emerging economies because it permits financial capital and financial resources from developed and prosperous countries to be invested in emerging, least developed and low saving economies but with high growth opportunities [25]. RBV theory states that firm resources (e.g., financial) can configure competitive advantage in an uncertain market [21]. Firms in emerging economies face a big problem of financial capital because the government does not provide adequate financial incentives to support them [19]. Hence, they look to external financial sources to expand their business operation [16]. Many newly established ventures in emerging economies benefit from foreign banks because they receive enough financial support from these banks (foreign banks) [25]. The foreign loan is deemed very beneficial for emerging firms due to a lack of internal financial support. In particular, the SME sector gets a big advantage of the foreign loan [26]. It is estimated that more than $95 \%$ of businesses are SMEs worldwide that contribute more than $60 \%$ to employment [14]. However, surprisingly, they face a big trouble in terms of financial capital which pushes them to rely on external (e.g., international) sources [27]. External (e.g., foreign) finance can stimulate SME performance directly, but many SMEs are unable to access the finance. Therefore, the responsible authorities (e.g., owners and managers) are required to strengthen their network with external bodies to make it easy to access the finance [28]. Foreign investment has been considered crucial for a long-term growth of the domestic firms. Moreover, it is deemed a prominent factor for a firm's innovation and competitive position [29]. Foreign banks help newly operated ventures and entrepreneurial firms to break various barriers which in turn facilitate gaining a sustainable competitive position in a turbulent market [30]. For instance, it is argued that international revenue significantly improves the sustainability of organizations [31]. It is doubtless that foreign direct investment plays a significant role in the improvement of business productivity, especially in emerging economies [32]. Therefore, the following hypothesis is proposed.

Hypothesis (H1). International Finance positively contributes to SCP. 


\subsection{International Technology and Sustainable Competitive Performance}

Some emerging economies such as Pakistan do not have modern technology to effectively support their business firms [11]. However, advanced technology is very crucial and can stimulate a competitive position of business industries [32]. Hence, many firms intend to adopt foreign technology, which can significantly enhance their performance [33]. External technology acquisition helps SMEs to increase their profitability and facilitate their sustainable competitiveness [34]. In competitive markets, those firms over perform who have the international technology for their operational activities [35]. Access to external technology is not only essential for new product development, but also empowers innovation performance [36]. Therefore, domestic firms try to capture foreign technology for their internal process in terms of product development, structure and skills. More preciously, firms with an international outlook (e.g., foreign technology) seem to have a greater capacity to gain SCP in the markets [37]. Emerging markets such as China encourages investment in international technology in order to increase the efficiency and competitiveness of her firms [38]. Advance technology of multinational companies enables host firms to seize a position in the market that provides a competitive position [39]. Having access to foreign technology, a host firm can easily promote trade with international firms. This linkage, in turn, provides high performance and competitiveness to the host firm [40]. Considering the weak performance of local firms in the market, encouraging foreign technology is the best strategy for emerging markets to stimulate industrial growth and performance [41]. International technology configures structure and process of the firms in a better way, which directly improves the innovation system. Moreover, international technology restructures the internal process which is helpful for the sustainability and competitiveness of the firms operating in emerging economies [1]. Foreign technology provides several benefits to emerging economies. However, from the business perspective, foreign technology can significantly improve industrial development and growth of business in emerging economies [42]. Therefore, the following hypothesis is proposed.

Hypothesis (H2). International Technology positively contributes to SCP.

\subsection{International Experience and Sustainable Competitive Performance}

Experience in international firms helps top management to acquire and utilize resources in an effective way by using international and external communication skills [43]. International experience helps business owners to build a competitive position in a dynamic market [23]. It is also suggested that such an experience has a direct and indirect influence on firm growth, performance and sustainability [44]. International experience does not only help business to enhance performance, but also facilitates firms to trade in the international markets easily [44]. It is helpful for firms in case of environmental sustainability and competitiveness [45]. It is argued that many SMEs fail due to the well-known reasons, lack of resource and lack of skills, etc. [16]. Hence, this alarming signal calls for competent and skilled managers who have spent time in foreign markets. Managers who have worked with international firms are able to transform their knowledge and ideas in an efficient way that enables a firm to gain superior performance [46]. Learning from foreign firms is deemed very important and a helpful strategy for underdeveloped firms as new ideas and experience are shared [47]. It is also discussed that international experience provides two major benefits, strategic change and high performance. Moreover, experience in international firms can enhance knowledge and general competencies of top management [48]. Top managers who have enough international trade experience know the international policies and practices. Hence, they promote the host firms to trade in international markets to increase their performance and efficiency [49]. Moreover, top managers who have worked in international markets for a long time can stimulate the international processes of the newly established host firms in an effective way to gain high profit [50]. International experience works as a resource and product newness for business sector organizations. It enhances firm performance in the host market [17]. Especially in emerging economies, foreign market knowledge and experience 
help organizations to access rare resources, which are beneficial for innovative performance and positioning [51]. Experience in foreign trade and business improves innovation performance and also helps to collect useful information that are required for organization competitiveness [52]. Therefore, the following hypothesis is proposed.

Hypothesis (H3). International Experience positively contributes to SCP.

\subsection{International Network and Sustainable Competitive Performance}

Firms operating in emerging economies do not receive adequate support from the government, financial institutions and Small and Medium Enterprise Development Authority (SMEDA) [53]. Hence, they often look for external assistance to survive in the long run in the turbulent markets [53]. Social network theory describes the importance of external ties and relationship that are helpful to get access to useful resources, which, in turn, can facilitate performance [16]. The international network helps firms to be internationally entrepreneurial orientated [54]. As pointed out by Bringmann and Vanoutrive and Verhetsel [55], firms with strong global ties and deep relationship acquire useful resources which configure their innovation competencies and performance while a firm with a lack of ties is often unable to compete effectively in the markets. Therefore, many valuable resources and capabilities can be gained through international network ties and relationship. For instance, SMEs, especially in emerging markets, are trying to build an international network in order to enter into foreign markets to gain high performance [56]. Many firms try to build the global network in order to identify novel opportunities [57], which, in turn, can facilitate high performance. Similarly, the international network helps firms to develop diversified products which are helpful in the achievement of a highly competitive position [58]. Foreign market experience, tie and knowledge stimulate the host ventures toward the international trade for the purpose to gain useful resources that are essential for high profit and competitiveness [59]. In particular, managerial ties provide the benefits of acquiring valuable resources that in turn configure a firm competitiveness and performance [60]. Participation in networks through cooperation in the supply chain, or partnerships with training institutes or local organizations can provide significant benefits to firms [61]. An organization with a strong international ties can enhance its sustainability and performance [62]. Therefore, the following hypothesis is proposed.

Hypothesis (H4). International Networking positively contributes to SCP.

\section{Methodology}

\subsection{Sample and Population}

For this research, data were collected from Pakistani manufacturing, trading and services SMEs. We obtained the registered firms list from Islamabad chamber of commerce and industry (e.g., around 4000 firms) and Rawalpindi chamber of commerce and industry (around 6000 firms). We asked the owners and top managers to participate in the survey because they are the responsible bodies and aware of their firm's operational activities [11].

\subsection{Procedure}

A convenience sampling technique is followed in this research. A hard copy approach was followed because an email survey gives a lower response rate in the emerging market Pakistan [16]. Thus, a total of 700 structured questionnaires was distributed among the firms. It was ensured in the questionnaire that the data received through this survey will be used only for the research purpose and will not be disclosed publicly. We received back 304 usable questionnaires with a response rate of $43.43 \%$. The profile of firms has shown in Table 2 . 
Table 2. Profile of the firms.

\begin{tabular}{|c|c|c|}
\hline Description & Frequency & Percentage \\
\hline \multicolumn{3}{|l|}{ Industry } \\
\hline 1. Manufacturing & 121 & 39.8 \\
\hline 2. Trading & 102 & 33.6 \\
\hline 3. Services & 81 & 26.6 \\
\hline \multicolumn{3}{|l|}{ Size } \\
\hline 1. $20-50$ employees & 40 & 13.2 \\
\hline 2. 51-100 employees & 43 & 14.1 \\
\hline 3. 101-150 employees & 88 & 28.9 \\
\hline 4. $151-200$ employees & 68 & 22.4 \\
\hline $\begin{array}{c}\text { 5. } 201-250 \text { employees } \\
\text { Age }\end{array}$ & Age & 21.4 \\
\hline 1. 10 years and less & 113 & 37.2 \\
\hline 2. $11-20$ years & 139 & 45.7 \\
\hline 3. 21 and above years & 52 & 17.1 \\
\hline \multicolumn{3}{|l|}{ Owners/Managers } \\
\hline 1. Oweners & 197 & 64.80 \\
\hline 2. Managers & 107 & 35.20 \\
\hline Total & 304 & 100 \\
\hline
\end{tabular}

\subsection{Measures}

International Finance: it refers to the finance provided by foreign banks and foreign financial institutions to businesses in a host country. To cover multiple dimensions of international finance, this research adopted the six items from the prior study [63]. However, the items are modified to match well in the current scenario as given in Table 5.

International Technology: it means the foreign technology available to firms in host countries for product development, delivery and operational process. We used three items that are adopted from past literature, but modified accordingly and have discussed in Table 5.

International Experience: it refers to the experience of international trade or international business. In other words, it means the top management international dealing. In order to measure international experience, we used five items (slightly modified) that were adopted from the prior study [16].

International Network: It means the relationship between top management (of a host firm) with international firms, suppliers and customers. We used three types of networks (see Table 5) that are essential for long-term survival as suggested by Wang, Ye and Tan [64].

Sustainable Competitive Performance: it is measured with different dimensions in prior studies. However, we relied on the comprehensive measures used by Mikalef and Pateli [65] where ten items are used to measure competitive performance.

Scale: in this research, 5-point Likert scales are used for all the independent variables showing strongly disagree 1 to strongly agree 5 . For the SCP, we also used 5-point Likert scales showing extremely declined 1 to extremely improved 5 .

\subsection{Control Variables}

This study controlled for the nature of the industry, size of firms and age of firms to reduce the spurious results. The factors are suggested by Anwar [11] to be controlled in SME studies. For the nature of the industry, we performed a group difference analysis (because of the categorical variable) in AMOS. The results provided no significant difference between manufacturing, trading and service industry. Hence, the nature of the industry was dropped instead of being controlled. However, age and size of firms were insignificantly related to SCP. 


\section{Analysis and Results}

Several statistical tests were applied in this research to analyze the data. Table 3 shows the descriptive statistics of the studied variables, after ordinal to numerical transformation. It indicates minimum, maximum, mean, standard deviation (S.D.) and data normality (skewness and kurtosis) of the sample. The highest mean value is of SCP (3.63) and the lowest mean value is of international finance (2.89). International technology has the highest S.D. (0.41) while international finance has the lowest S.D. (0.29). The results show that the data are normal as all the factors have their skewness and kurtosis values lower than the cutoff \pm 2 as suggested by George [66].

Table 3. Descriptive statistics.

\begin{tabular}{lcccccc}
\hline \multicolumn{1}{c}{ Variables } & Min & Max & Mean & S.D. & Skewness & Kurtosis \\
\hline International Finance & 1.65 & 3.64 & 2.8881 & 0.29484 & -0.854 & 0.826 \\
International Technology & 1.94 & 4.76 & 3.5727 & 0.41244 & -1.217 & 1.421 \\
International Experience & 2.45 & 4.10 & 3.0461 & 0.33688 & 0.033 & 0.500 \\
International Network & 2.65 & 4.35 & 3.3488 & 0.30759 & -1.330 & 0.834 \\
SCP & 2.96 & 4.87 & 3.6324 & 0.38188 & -0.523 & -0.603 \\
\hline
\end{tabular}

\subsection{Common Method Bias (CMB)}

This research checked CMB because data were collected through a single source (questionnaire), at the same time and from the same respondents. We executed the Harman's one-factor test in the Statistical Package for the Social Sciences (SPSS) to check the potential threat of the CMB. We found five factors that have eigenvalues greater than 1 of which the first factor explained only $27.79 \%$ variance, which is less than $50 \%$ and thus confirmed the absence of the CMB in this research [67].

\subsection{Confirmatory Factor Analysis (CFA)}

CFA was performed in AMOS to check the factors loading, validity and reliability of the factors. First, we executed a measurement model that has been shown in Figure 1. The model fits (see Table 4) are found in the acceptable range as the value of $\chi^{2} / \mathrm{df}$ is less than 3 , which shows an acceptable model fit as suggested by the prior studies [68,69]. Goodness of Fit Index (GFI), Adjusted Goodness of Fit Index (AGFI), Trucker Levis Index (TLI) and Normative Fit Index (NFI) values are greater than or closer to 0.90, which confirmed model fits as recommended by the prior studies [68-70]. Root Mean square Residual (RMR) and Root Mean Square Error of Approximation (RMSEA) are also found in the acceptable range (less than 0.080), which show an acceptable model fit [68,69]. All of the items are loaded significantly (see Table 5) on their respective variables $(p<0.001)$.

Convergent validity is calculated to know if the items explain enough variance in their respective constructs. If the value is greater than 0.50 , then the items explain enough variance which confirms that Average Variance Extraction (AVE) is achieved [68,69]. All of the variables that have acceptable values (above 0.50) in this research are shown in Table 6.

Discriminant validity is calculated to know if the items explain unique variance in the respective variables and the items are not overlapping with each other. It is calculated by taking the square root of AVE and is presented as $\sqrt{ }$ AVE (see Table 6). The acceptable value for discriminant validity is 0.70 and above as recommended [68-70]. The results show that all the factors have acceptable values (above 0.70) for discriminant validity, which confirm that the items are unique and do not overlap.

Composite reliability indicates the internal consistency of the items toward a specific factor. The acceptable value is 0.70 [71]. All the factors have composite reliability greater than 0.70 (see Table 6), which confirmed that the items are reliable. Hence, all the criteria for the measurement model are fulfilled. 
Table 4. Model fits.

\begin{tabular}{cccccccc}
\hline Models & $\chi^{2} / \mathbf{d f}$ & GFI & AGFI & NFI & TLI & RMR & RMSEA \\
\hline Measurement Model & 1.882 & 0.87 & 0.85 & 0.87 & 0.93 & 0.011 & 0.054 \\
Structural Model & 2.150 & 0.85 & 0.82 & 0.84 & 0.90 & 0.017 & 0.062 \\
\hline
\end{tabular}

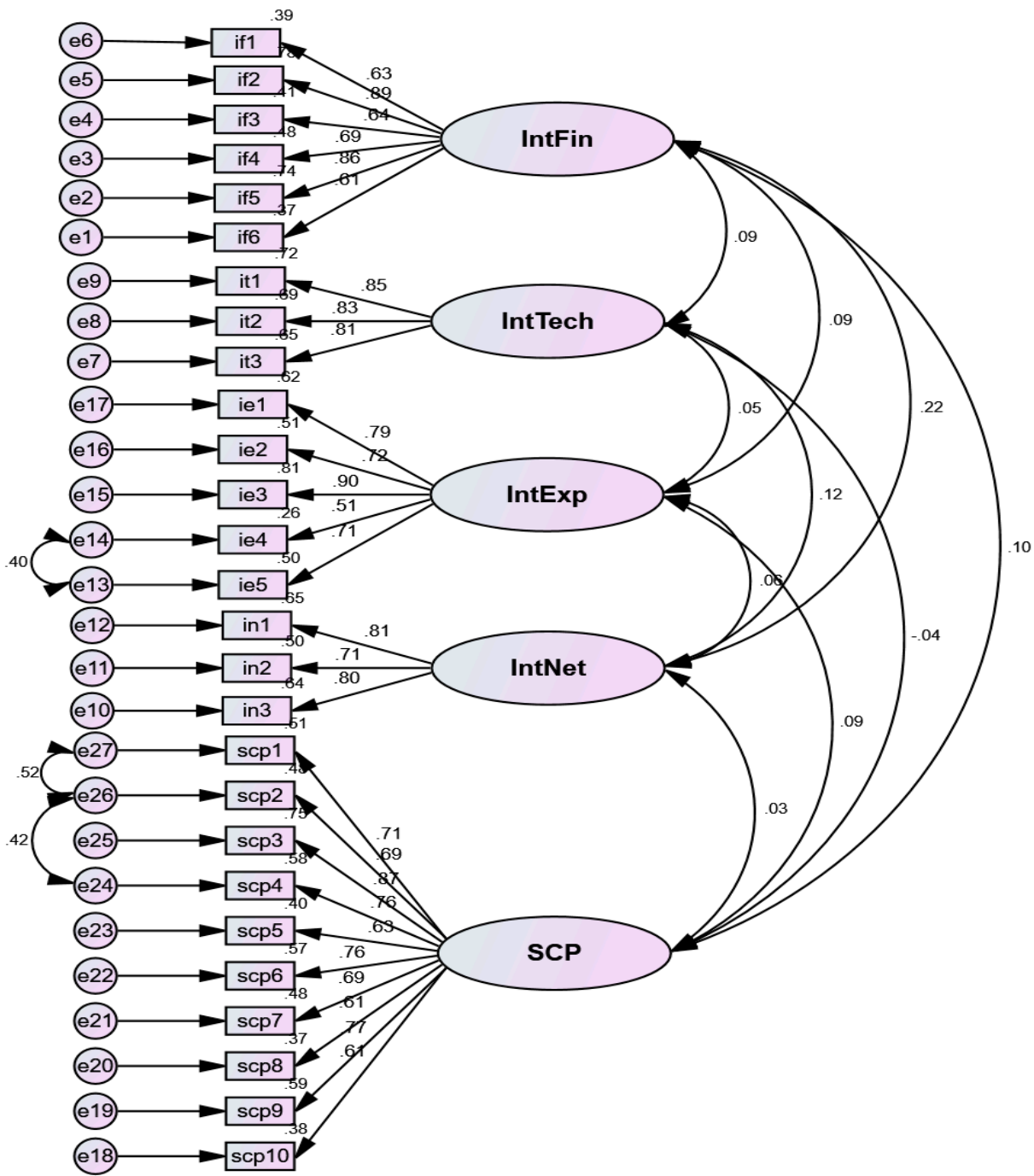

Figure 1. Measurement model.

Table 5. Factor loading.

\begin{tabular}{lc}
\hline \multicolumn{1}{c}{ Items } & Estimate \\
\hline \multicolumn{1}{c}{ International Finance } & 0.626 \\
1. My firm can access sufficient foreign equity funding available for growing firms & 0.885 \\
2. My firm can obtain sufficient foreign debt funding available for growing firms & 0.639 \\
3. My firm can access sufficient foreign financial subsidies available for growing firms & 0.695 \\
4. My firm can access adequate financing available from foreign individuals (other than \\
founders) for growing firms \\
$\begin{array}{l}\text { 5. My firm can obtain sufficient international venture capitalist funding available for } \\
\text { growing firms }\end{array}$ \\
$\begin{array}{l}\text { 6. My firm can access sufficient funding available through foreign initial public offerings } \\
\text { (IPOs) for growing firms }\end{array}$ \\
\hline
\end{tabular}


Table 5. Cont.

\begin{tabular}{|c|c|}
\hline Items & Estimate \\
\hline \multicolumn{2}{|l|}{ International Technology } \\
\hline $\begin{array}{l}\text { 1. My firm can access advanced foreign technology available for development of new } \\
\text { products and services }\end{array}$ & 0.851 \\
\hline 2. My firm can obtain advanced foreign technology available for delivery process & 0.829 \\
\hline $\begin{array}{l}\text { 3. My firm can access advanced foreign technology available for operational and } \\
\text { administrative process }\end{array}$ & 0.808 \\
\hline \multicolumn{2}{|l|}{ International Experience } \\
\hline 1. Less than 5 years' experience & 0.787 \\
\hline 2. 6 to 10 years' experience & 0.717 \\
\hline 3. 11 to 15 years' experience & 0.902 \\
\hline 4. 16 to 20 years' experience & 0.505 \\
\hline 5. 21 and above years' experience & 0.705 \\
\hline \multicolumn{2}{|l|}{ International Network } \\
\hline 1. We have a strong relationship with international customers & 0.806 \\
\hline 2. We have a strong relationship with international suppliers & 0.708 \\
\hline 3. We have a strong relationship with international business firms & 0.802 \\
\hline \multicolumn{2}{|l|}{ Sustainable Competititve Performance } \\
\hline 1. Return on investment (ROI) & 0.711 \\
\hline 2. Profits as a percentage of sales & 0.693 \\
\hline 3. Decreasing product or service delivery cycle time & 0.865 \\
\hline 4. Rapid response to market demand & 0.764 \\
\hline 5. Rapid confirmation of customer orders & 0.629 \\
\hline 6. Increasing customer satisfaction & 0.756 \\
\hline 7. In profit growth rates & 0.691 \\
\hline 8. In reducing operating costs & 0.611 \\
\hline 9. Providing better product and service quality & 0.770 \\
\hline 10. Increasing our market share & 0.613 \\
\hline
\end{tabular}

Table 6. Correlation coefficients.

\begin{tabular}{llcccccccc}
\hline \multicolumn{1}{c}{ Factors } & AVE & $\mathbf{1}$ & $\mathbf{2}$ & $\mathbf{3}$ & $\mathbf{4}$ & $\mathbf{5}$ & $\mathbf{6}$ & $\mathbf{7}$ \\
\hline 1. & Size & - & 1 & & & & & & \\
2. & Age & - & $0.113^{*}$ & 1 & & & & & \\
3. & International Finance & 0.53 & -0.013 & 0.066 & $(0.73)$ & & & & \\
4. International Technology & 0.69 & -0.022 & -0.075 & 0.041 & $(0.83)$ & & & \\
5. & International Experience & 0.54 & -0.023 & 0.080 & $0.138^{*}$ & 0.024 & $(0.73)$ & & \\
6. & International Network & 0.60 & -0.047 & -0.072 & $0.233^{* *}$ & 0.069 & $0.129^{*}$ & $(0.77)$ & \\
7. & SCP & 0.51 & 0.033 & 0.016 & $0.329^{* *}$ & $0.135^{*}$ & $0.384^{* *}$ & $0.469^{* *}$ & $(0.71)$ \\
& Composite Reliability & - & - & - & 0.87 & 0.87 & 0.86 & 0.82 & 0.89 \\
\hline
\end{tabular}

Note: ${ }^{* *}$ Significant at level $(p<0.01),{ }^{*}$ significant at level $(p<0.05)$. AVE=Average Variance Extracted.

\subsection{Correlation Coefficients}

This research executed the Pearson correlation in SPSS and the results are shown in Table 6. It shows that international finance is significantly positively related to SCP $(\mathrm{r}=0.329, p<0.01)$, international technology is also significantly positively related to SCP $(r=135, p<0.05)$, there is a significant positive relationship between international experience and SCP $(0.384, p<0.01)$ and international networking is significantly positively related to SCP $(r=0.469, p<0.01)$. The results show that there is no multicollinearity problem as none of the correlation values is greater than 0.80 [11].

\subsection{Structural Model}

Structural model in AMOS was applied to test the hypotheses of the research (see Figure 2). First, we confirmed the model fits in terms of $\chi^{2} / \mathrm{df}$, which provided a good model fit as it is less than 3 [68-70], and GFI, AGFI, TLI and NFI are also provided acceptable values (above or close to 0.90) as per the recommendation of the prior studies [68-70]. 
The results (see Table 7) show that international finance has a significant positive influence on SCP ( $\beta=0.250, p<0.05)$, which accepted H1. International technology does not have a significant influence on SCP $(\beta=0.085, p>0.05)$, and does not support it. International experience has a significant influence on SCP $(\beta=0.326, p<0.05)$, which supported H3. Finally, the results show that international network has a significant influence on SCP $(\beta=0.431, p<0.05)$, which supported H4. Both of the control variables, age and size of firms have an insignificant influence on SCP. R square value depicts that the factors (international finance, international technology, international experience and international network) explain $29 \%$ variance in SCP in the presence of age and size of firms as control variables.

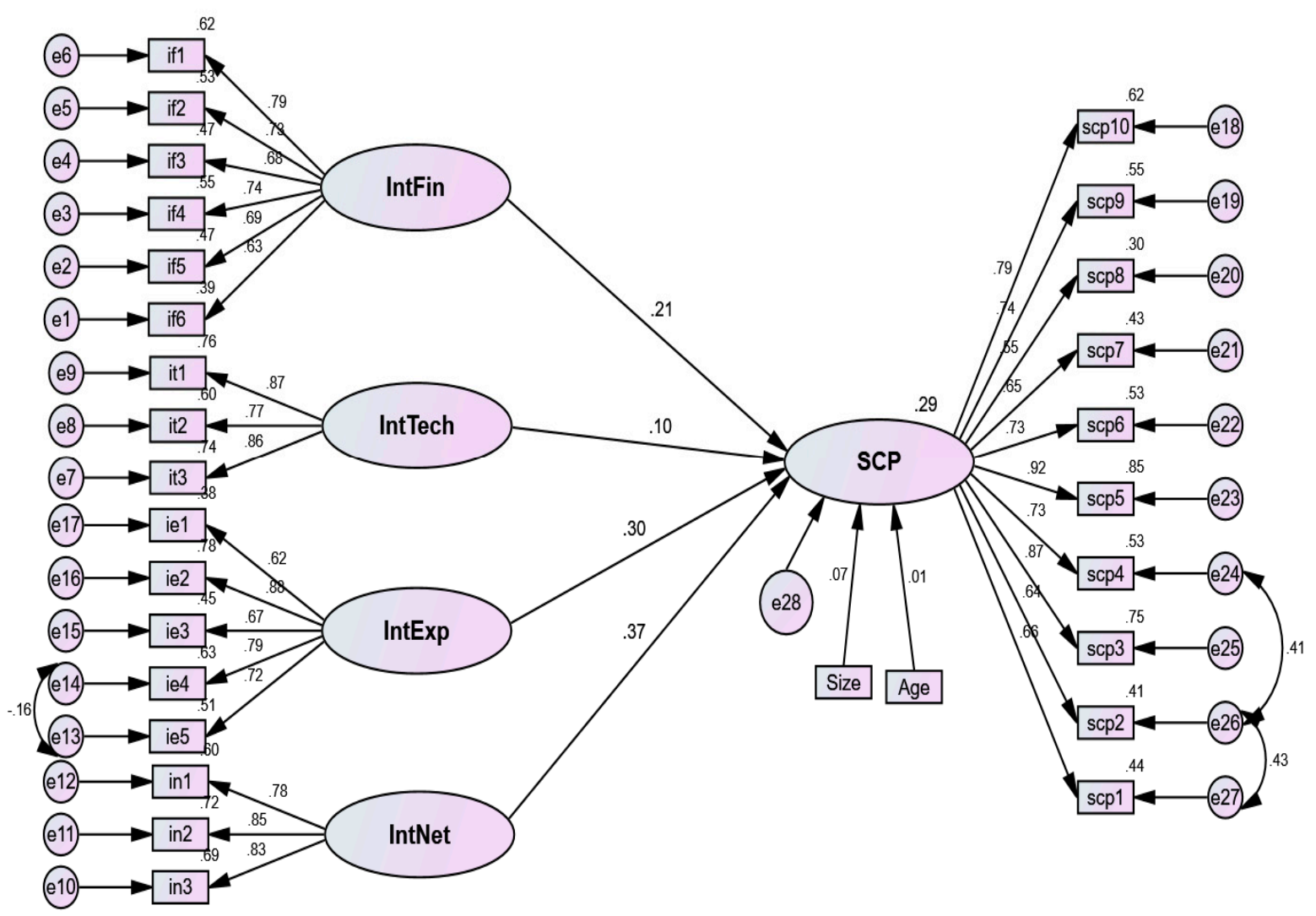

Figure 2. Structural model.

Table 7. Hypothesis testing.

\begin{tabular}{rrcccccc}
\hline & \multicolumn{2}{c}{ Hypotheses } & Estimate & S.E. & C.R. & $p$ & Remarks \\
\hline H1. SCP & $<-$ & International Finance & 0.250 & 0.071 & 3.536 & 0.000 & accepted \\
H2. SCP & $<-$ & International Technology & 0.085 & 0.048 & 1.765 & 0.078 & Rejected \\
H3. SCP & $<-$ & International Experience & 0.326 & 0.064 & 5.130 & 0.000 & accepted \\
H4. SCP & $<-$ & International Network & 0.431 & 0.070 & 6.177 & 0.000 & accepted \\
SCP & $<-$ & Age & 0.003 & 0.026 & 0.133 & 0.894 & - \\
SCP & $<-$ & Size & 0.021 & 0.016 & 1.297 & 0.195 & - \\
\hline
\end{tabular}

\subsection{Robustness Test}

For the check for robustness, we executed regression analysis in SPSS (see Table 8). We used the same variables; international finance, international technology, international experience and international networking as independent variables and SCP as a dependent variable in the presence of two control variables: size and age of the firms. The results endorsed AMOS and confirmed that only the international technology is not a significant predictor of SCP while international finance, international experience and international networking have a significant influence on SCP. 
Table 8. Regression analysis.

\begin{tabular}{|c|c|c|c|c|c|c|}
\hline & \multirow[t]{2}{*}{ Model } & \multicolumn{2}{|c|}{$\begin{array}{c}\text { Unstandardized } \\
\text { Coefficients }\end{array}$} & \multirow{2}{*}{$\begin{array}{c}\begin{array}{l}\text { Standardized } \\
\text { Coefficients }\end{array} \\
\text { Beta }\end{array}$} & \multirow[t]{2}{*}{$\mathbf{t}$} & \multirow[t]{2}{*}{ Sig. } \\
\hline & & B & Std. Error & & & \\
\hline \multirow{3}{*}{1} & (Constant) & 3.556 & 0.077 & & 45.914 & 0.000 \\
\hline & Size & 0.013 & 0.017 & 0.043 & 0.750 & 0.454 \\
\hline & Age & 0.020 & 0.031 & 0.036 & 0.627 & 0.531 \\
\hline \multirow{7}{*}{2} & (Constant) & -0.136 & 0.301 & & -0.451 & 0.652 \\
\hline & Size & 0.019 & 0.014 & 0.064 & 1.395 & 0.164 \\
\hline & Age & 0.015 & 0.025 & 0.028 & 0.604 & 0.547 \\
\hline & International Finance & 0.249 & 0.062 & 0.192 & 4.037 & 0.000 \\
\hline & International Technology & 0.090 & 0.043 & 0.098 & 1.942 & 0.053 \\
\hline & International Experience & 0.346 & 0.053 & 0.305 & 6.545 & 0.000 \\
\hline & International Network & 0.473 & 0.059 & 0.381 & 8.011 & 0.000 \\
\hline
\end{tabular}

Note: Dependent variable: SCP.

\section{Discussion}

This research examines the influence of international finance, international technology, international experience and international network on SCP among SMEs operating in the emerging market in Pakistan. However, many studies have examined the role of foreign direct investment, international experience and networking in firm performance, but the role of the certain factors in SCP has been ignored. This research contributes to the existing literature by collecting empirical evidence from manufacturing, trading and service SMEs. Very rare studies have examined the role of certain capabilities in terms of social networking and RBV theory. Hence, insights derived from this study are very useful theoretically as well as practically.

The results show that international finance has a significant influence on SCP which supported the H1. In line with Giannetti and Ongena [25], who argued that there is a lack of financial support and lack of financial incentive for SMEs in emerging economies. Hence, they often look for foreign funding and support. Similarly, Anwar and Shah [16] also claimed that there is a high interest rate for the business sector in emerging economies. Hence, they intend foreign funding as less expensive to gain SCP [30]. The international finance is not only significant for Asian firms. SMEs in European markets also face a shortage of financial resources and they get benefits of external finance (e.g., finance offered by other developed markets in a host developed country) to expand their operation [72]. We support the argument that external funding is very crucial for SMEs in the emerging market in Pakistan to smooth their operation.

This research found that international technology does not have a significant influence on SCP, which did not support the H2. Unlike Buckley et al. [33], who scrutinized that the international technology significantly improves the performance of host firms, this study concluded that the international technology does not significantly contribute to SCP in the emerging market Pakistan. Our findings favor Chae, Koh and Park [73], who confirmed that IT leaders firms do not always significantly grow as compared to the firms having low IT capabilities. The reason may be that firms in Pakistan are unable to access expensive technology due to a lack of financial capabilities.

The results show that international experience significantly and positively contributes to SCP that confirmed the H3. The findings are consistent with Zeng, Xie and Tam [52], who resulted that experience in international trade and international business gives the advantage to host firms in the achievement of a highly competitive position. Moreover, Hollender, Zapkau and Schwens [17] also claimed that international experience facilitates top managers to acquire useful resources easily. Considering the international experience in USA firms, Le and Kroll [48] claimed CEOs who have spent their time in international firms can significantly improve the performance of host firms.

Finally, this study confirmed that international network is a significant predictor of SCP, which supported the H4, in line with Hilmersson and Jansson [56], who demonstrated that the 
international network enables host firms to build a strong connection with international partners, which, in turn, supports the achievement of SCP. In addition, firms in developed markets also gain high performance and growth through an international network and relationship [74]. We confirmed the significant role of international relations in emerging firms as it enhances superior performance.

\section{Implications}

This research suggests several implications for top management, policymakers and responsible bodies to focus on the international capabilities and resources. This research delineates that international finance, international experience and international network significantly contributes to SCP in SMEs. As it was pointed out, SMEs in emerging economies face a lack of resources that hinder their growth in a turbulent market. This research recommends owners and managers of SMEs to access less expensive foreign loans to gain SCP. Moreover, this research suggests the top management team to build a strong tie with international partners, which, in turn, gives beneficial outcomes. This research also recommends host firms to hire internationally experienced managers who can easily trade in global markets and are aware of international transactions. For instance, emerging economies do not provide an adequate and suitable culture of a successful business, hence firms in such regions often tend to gain international resources. This research delineates and discloses which particular international resource or capability is useful in the achievement of SCP. Alternatively, this research encourages policymakers to support international partners, foreign investors and international technology in the host countries to enhance the growth and survival of the business sector. The results show that international technology is not a significant predictor of SCP, hereby suggesting the promotion of foreign and advanced technology that can enable the host firms in new product developments and process in future operation. Free trade agreements will be supported in this perspective to expand international transactions between the host and foreign markets.

Moreover, this research strongly recommends SMEDA to modify their strategies and policies to encourage the relationship between foreign and local firms. For instance, CPEC (China Pakistan Economic Corridor) is going to launch its operation very soon. This trade route will result in massive transactions in international markets. Therefore, SMEDA and government need to keep the SMEs ready for this opportunity (e.g., CPEC) to get benefits of international technology, international finance, international experience and networking. This study does not only encourage SMEs and policymakers in the emerging market Pakistan but also gives equal weight to the importance of the certain international resources and capabilities in other countries.

\section{Conclusions}

The role of various international resources and capabilities in a host firm performance is extensively discussed by the prior studies. However, the importance of some prominent international capabilities and resources is still missing despite their significant role in the success of the host business firms. We targeted the missing gap in the existing literature and focused on the role of international finance, international technology, international experience and international network in SCP of host firms. This research is based on social network theory and RBV theory, where the role of international finance, international technology, international experience and international network in SCP are tested. To avoid bias insights, data were collected from 304 Pakistani SMEs (e.g., manufacturing, trading and services) through a structured questionnaire. Hypotheses were tested through SEM in AMOS as well as executed regression analysis in SPSS as a robustness check. The results indicate that international finance, international experience and international network significantly and positively contribute to SCP while international technology is not a significant predictor of SCP. Our findings favor several studies that are conducted in developed and emerging economies in the relevant context. For instance, from the importance of international finance perspective, our findings favor Bougheas et al. [72], who pointed out that international finance is essential for a host firm to expand its business in other markets and grow speedily. Our results do not show a significant influence of international technology 
on SCP. The findings are related to Chae, Koh and Park [73], who scrutinized that IT leaders do not always outperform over those firms who have low technological capabilities. However, from the international experience perspective, our results favor Le and Kroll [48] who indicate that CEOs that have spent time in international markets can modify and utilize resources in efficient ways that enable host firms to gain SCP. Similarly, the results also favor Oehme and Bort [74], who pointed out that international relation is considered as an important factor for firms to improve profitability and sustainable position in a turbulent market. This research encourages top managers and policy makers to give enough attention to the international resources and capabilities to configure their firm survival in the turbulent market.

\section{Limitations and Future Research}

This research has discussed several implications for practicing managers and contributes to the existing theories of social network and RBV. However, there are a few limitations that should be addressed in future studies. For instance, this research is conducted in the emerging market in Pakistan that may not be a good representative of all the emerging economies. Researchers from other emerging and transition economies are encouraged to extend this research. We targeted only SMEs; however, large firms also face several shortcomings to survive in the turbulent markets. Hence, large firms should be surveyed in future studies to acquire more useful insights. We tested the direct impact of international finance, international technology, international experience and international networking on SCP. However, Dolfsma and Van der Eijk [75] claimed that innovation could mediate the relationship between networking and firm performance. We, as a result of this, recommend the role of innovation to be tested between the international resources/capabilities and SCP to explore valuable understandings. A comparative study between emerging and developed SMEs can unleash more advantageous outputs.

Author Contributions: All of the authors equally contributed to the paper.

Funding: This research received no external funding.

Conflicts of Interest: The authors have no conflict of interest.

\section{References}

1. Fu, X.; Pietrobelli, C.; Soete, L. The role of foreign technology and indigenous innovation in the emerging economies: Technological change and catching-up. World Dev. 2011, 39, 1204-1212. [CrossRef]

2. Andrieș, A.; Marcu, N.; Oprea, F.; Tofan, M. Financial Infrastructure and Access to Finance for European SMEs. Sustainability 2018, 10, 3400. [CrossRef]

3. Berge, L.I.O.; Bjorvatn, K.; Tungodden, B. Human and financial capital for microenterprise development: Evidence from a field and lab experiment. Manag. Sci. 2014, 61, 707-722. [CrossRef]

4. Khan, S.Z.; Yang, Q.; Waheed, A. Investment in intangible resources and capabilities spurs sustainable competitive advantage and firm performance. Corp. Soc. Responsibility Environ. Manag. 2018. [CrossRef]

5. Vetráková, M.; Hitka, M.; Potkány, M.; Lorincová, S.; Smerek, L. Corporate Sustainability in the Process of Employee Recruitment through Social Networks in Conditions of Slovak Small and Medium Enterprises. Sustainability 2018, 10, 1670. [CrossRef]

6. Wang, H.; Han, P.; Liu, W. How to Improve Sustainable Competitive Advantage from the Distributor and the Supplier Networks: Evidence from the Paper-Making Industry in China. Sustainability 2018, 10, 2038. [CrossRef]

7. Lyver, M.J.; Lu, T.-J. Sustaining Innovation Performance in SMEs: Exploring the Roles of Strategic Entrepreneurship and IT Capabilities. Sustainability 2018, 10, 442. [CrossRef]

8. Ge, B.; Yang, Y.; Jiang, D.; Gao, Y.; Du, X.; Zhou, T. An Empirical Study on Green Innovation Strategy and Sustainable Competitive Advantages: Path and Boundary. Sustainability 2018, 10, 3631. [CrossRef]

9. Widya-Hasuti, A.; Mardani, A.; Streimikiene, D.; Sharifara, A.; Cavallaro, F. The Role of Process Innovation between Firm-Specific Capabilities and Sustainable Innovation in SMEs: Empirical Evidence from Indonesia. Sustainability 2018, 10, 2244. [CrossRef] 
10. Kim, H.; Kim, E. How an Open Innovation Strategy for Commercialization Affects the Firm Performance of Korean Healthcare IT SMEs. Sustainability 2018, 10, 2476. [CrossRef]

11. Anwar, M. Business Model Innovation and SMEs Performance-Does Competitive Advantage Mediate? Int. J. Innov. Manag. 2018, 22, 1850057. [CrossRef]

12. Guo, H.; Tang, J.; Su, Z.; Katz, J.A. Opportunity recognition and SME performance: The mediating effect of business model innovation. RED Manag. 2017, 47, 431-442.

13. Kamukama, N.; Sulait, T. Intellectual capital and competitive advantage in Uganda's microfinance industry. Afr. J. Econ. Manag. Stud. 2017, 8, 498-514. [CrossRef]

14. Anwar, M.; Khan, S.Z.; Khan, N.U. Intellectual Capital, Entrepreneurial Strategy and New Ventures Performance: Mediating Role of Competitive Advantage. Bus. Econ. Rev. 2018, 10, 63-94. [CrossRef]

15. Jain, P.; Vyas, V.; Roy, A. Exploring the mediating role of intellectual capital and competitive advantage on the relation between CSR and financial performance in SMEs. Soc. Responsibility J. 2017, 13, 1-23. [CrossRef]

16. Anwar, M.; Ali Shah, S.Z. Managerial Networking and Business Model Innovation: Empirical Study of New Ventures in an Emerging Economy. J. Small Bus. Entrep. 2018, 1-22. [CrossRef]

17. Hollender, L.; Zapkau, F.B.; Schwens, C. SME foreign market entry mode choice and foreign venture performance: The moderating effect of international experience and product adaptation. Int. Bus. Rev. 2017, 26, 250-263. [CrossRef]

18. Rahman, M.; Uddin, M.; Lodorfos, G. Barriers to enter in foreign markets: Evidence from SMEs in emerging market. Int. Mark. Rev. 2017, 34, 68-86. [CrossRef]

19. Anwar, M.; Shah, S.Z.A.; Khan, S.Z. The role of personality in SMEs internationalization: Empirical evidence. Rev. Int. Bus. Strategy 2018, 28, 258-282. [CrossRef]

20. Estrin, S.; Nielsen, B.B.; Nielsen, S. Emerging market multinational companies and internationalization: The role of home country urbanization. J. Int. Manag. 2017, 23, 326-339. [CrossRef]

21. Barney, J. Firm resources and sustained competitive advantage. J. Manag. 1991, 17, 99-120. [CrossRef]

22. Medcof, J.W. Resource-based strategy and managerial power in networks of internationally dispersed technology units. Strateg. Manag. J. 2001, 22, 999-1012. [CrossRef]

23. Camisón, C.; Villar-López, A. Effect of SMEs' international experience on foreign intensity and economic performance: The mediating role of internationally exploitable assets and competitive strategy. J. Small Bus. Manag. 2010, 48, 116-151. [CrossRef]

24. Burt, R.S.; Kilduff, M.; Tasselli, S. Social network analysis: Foundations and frontiers on advantage. Ann. Rev. Psychol. 2013, 64, 527-547. [CrossRef] [PubMed]

25. Giannetti, M.; Ongena, S. Financial integration and firm performance: Evidence from foreign bank entry in emerging markets. Rev. Financ. 2009, 13, 181-223. [CrossRef]

26. Kim, Y.J.; Tesar, L.L.; Zhang, J. The impact of foreign liabilities on small firms: Firm-level evidence from the Korean crisis. J. Int. Econ. 2015, 97, 209-230. [CrossRef]

27. Quartey, P.; Turkson, E.; Abor, J.Y.; Iddrisu, A.M. Financing the growth of SMEs in Africa: What are the contraints to SME financing within ECOWAS? Rev. Dev. Financ. 2017, 7, 18-28. [CrossRef]

28. St-Pierre, J.; Sakka, O.; Bahri, M. External Financing, Export Intensity and Inter-Organizational Collaborations: Evidence from Canadian SMEs. J. Small Bus. Manag. 2018, 56, 68-87. [CrossRef]

29. Bena, J.; Ferreira, M.A.; Matos, P.; Pires, P. Are foreign investors locusts? The long-term effects of foreign institutional ownership. J. Financ. Econ. 2017, 126, 122-146. [CrossRef]

30. Rajan, R.G.; Zingales, L. The great reversals: The politics of financial development in the twentieth century. J. Financ. Econ. 2003, 69, 5-50. [CrossRef]

31. Tan, Y.; Ochoa, J.J.; Langston, C.; Shen, L. An empirical study on the relationship between sustainability performance and business competitiveness of international construction contractors. J. Clean. Prod. 2015, 93, 273-278. [CrossRef]

32. Liang, F.H. Does foreign direct investment improve the productivity of domestic firms? Technology spillovers, industry linkages, and firm capabilities. Res. Policy 2017, 46, 138-159. [CrossRef]

33. Buckley, P.J.; Munjal, S.; Enderwick, P.; Forsans, N. Do foreign resources assist or impede internationalisation? Evidence from internationalisation of Indian multinational enterprises. Int. Bus. Rev. 2016, 25, 130-140. [CrossRef]

34. Subrahmanya, M. External Technology Acquisition and Economic Performance of Small and Medium Enterprises (SMES) in Bangalore: An Empirical Analysis. Technol. Transf. Entrep. 2015, 2, 101-111. [CrossRef] 
35. Kim, J.Y.; Steensma, H.K.; Park, H.D. The influence of technological links, social ties, and incumbent firm opportunistic propensity on the formation of corporate venture capital deals. J. Manag. 2017. [CrossRef]

36. Gnekpe, C.; Coeurderoy, R. The impact of internal and external technology sourcing on innovation performance: A review and research agenda. Int. J. Technol. Manag. 2017, 73, 21-38. [CrossRef]

37. Lafi, M. Foreign Affiliates and Technology Spillovers in the French Manufacturing Sector: An Analysis using Panel Data. Int. J. Econ. Financ. Issues 2018, 8, 229-242.

38. Grimes, S.; Yang, C. From foreign technology dependence towards greater innovation autonomy: China's integration into the information and communications technology (ICT) global value chain (GVC). Area Dev. Policy 2018, 3, 132-148. [CrossRef]

39. Xing, Y. Global Value Chains and China's Exports to High-income Countries. Int. Econ. J. 2016, 30, $191-203$. [CrossRef]

40. Zhou, Y. The Inside Story of China's High-Tech Industry: Making Silicon Valley in Beijing; Rowman \& Littlefield Publishers: Lanham, MD, USA, 2007.

41. Sun, Y.; Grimes, S. China's increasing participation in ICT's global value chain: A firm level analysis. Telecommun. Policy 2016, 40, 210-224. [CrossRef]

42. Dunmade, I. Indicators of sustainability: Assessing the suitability of a foreign technology for a developing economy. Technol. Soc. 2002, 24, 461-471. [CrossRef]

43. Fonseca, L.M.; Domingues, J.P. Exploratory Research of ISO 14001: 2015 Transition among Portuguese Organizations. Sustainability 2018, 10, 781. [CrossRef]

44. Mohr, A.; Batsakis, G. Intangible assets, international experience and the internationalisation speed of retailers. Int. Mark. Rev. 2014, 31, 601-620. [CrossRef]

45. Aguilera-Caracuel, J.; Hurtado-Torres, N.E.; Aragón-Correa, J.A. Does international experience help firms to be green? A knowledge-based view of how international experience and organisational learning influence proactive environmental strategies. Int. Bus. Rev. 2012, 21, 847-861. [CrossRef]

46. Emden, Z.; Yaprak, A.; Cavusgil, S.T. Learning from experience in international alliances: Antecedents and firm performance implications. J. Bus. Res. 2005, 58, 883-892. [CrossRef]

47. Iliev, P.; Roth, L. Learning from directors' foreign board experiences. J. Corp. Financ. 2018, 51, 1-19. [CrossRef]

48. Le, S.; Kroll, M. CEO international experience: Effects on strategic change and firm performance. J. Int. Bus. Stud. 2017, 48, 573-595. [CrossRef]

49. Berne, C.; Garcia-Uceda, M.E. Criteria involved in evaluation of trade shows to visit. Ind. Mark. Manag. 2008, 37, 565-579. [CrossRef]

50. Gruenhagen, J.H.; Sawang, S.; Gordon, S.R.; Davidsson, P. International experience, growth aspirations, and the internationalisation of new ventures. J. Int. Entrep. 2018, 16, 421-440. [CrossRef]

51. Williams, C.; Colovic, A.; Zhu, J. Foreign market knowledge, country sales breadth and innovative performance of emerging economy firms. Int. J. Innov. Manag. 2016, 20, 1650059. [CrossRef]

52. Zeng, S.X.; Xie, X.M.; Tam, C.M. Relationship between cooperation networks and innovation performance of SMEs. Technovation 2010, 30, 181-194. [CrossRef]

53. Songling, Y.; Ishtiaq, M.; Anwar, M.; Ahmed, H. The role of government support in sustainable competitive position and firm performance. Sustainability 2018, 10, 3495. [CrossRef]

54. Yoon, J.; Kim, K.K.; Dedahanov, A.T. The Role of International Entrepreneurial Orientation in Successful Internationalization from the Network Capability Perspective. Sustainability 2018, 10, 1709. [CrossRef]

55. Bringmann, K.; Vanoutrive, T.; Verhetsel, A. Venture capital: The effect of local and global social ties on firm performance. Pap. Reg. Sci. 2018, 97, 737-755. [CrossRef]

56. Hilmersson, M.; Jansson, H. International network extension processes to institutionally different markets: Entry nodes and processes of exporting SMEs. Int. Bus. Rev. 2012, 21, 682-693. [CrossRef]

57. Sigfusson, T.; Chetty, S. Building international entrepreneurial virtual networks in cyberspace. J. World Bus. 2013, 48, 260-270. [CrossRef]

58. Patel, P.C.; Fernhaber, S.A.; McDougall-Covin, P.P.; van der Have, R.P. Beating competitors to international markets: The value of geographically balanced networks for innovation. Strateg. Manag. J. 2014, 35, 691-711. [CrossRef]

59. Musteen, M.; Datta, D.K.; Butts, M.M. Do International Networks and Foreign Market Knowledge Facilitate SME Internationalization? Evidence From the C zech R epublic. Entrep. Theory Pract. 2014, 38, 749-774. [CrossRef] 
60. Li, J.J.; Zhou, K.Z. How foreign firms achieve competitive advantage in the Chinese emerging economy: Managerial ties and market orientation. J. Bus. Res. 2010, 63, 856-862. [CrossRef]

61. Graafland, J.J. Ecological impacts of the ISO14001 certification of small and medium sized enterprises in Europe and the mediating role of networks. J. Clean. Prod. 2018, 174, 273-282. [CrossRef]

62. Ward, H. International linkages and environmental sustainability: The effectiveness of the regime network. J. Peace Res. 2006, 43, 149-166. [CrossRef]

63. Zamberi Ahmad, S.; Xavier, S.R. Entrepreneurial environments and growth: Evidence from Malaysia GEM data. J. Chin. Entrep. 2012, 4, 50-69. [CrossRef]

64. Wang, Z.; Ye, F.; Tan, K.H. Effects of managerial ties and trust on supply chain information sharing and supplier opportunism. Int. J. Prod. Res. 2014, 52, 7046-7061. [CrossRef]

65. Mikalef, P.; Pateli, A. Information technology-enabled dynamic capabilities and their indirect effect on competitive performance: Findings from PLS-SEM and fsQCA. J. Bus. Res. 2017, 70, 1-16. [CrossRef]

66. George, D. SPSS for Windows Step by Step: A Simple Study Guide and Reference, 17.0 Update, 10/e; Pearson Education: London, UK, 2011.

67. Podsakoff, P.M.; Organ, D.W. Self-reports in organizational research: Problems and prospects. J. Manag. 1986, 12, 531-544. [CrossRef]

68. Hair, J.F.; Anderson, R.E.; Babin, B.J.; Black, W.C. Multivariate Data Analysis: A Global Perspective (Vol. 7); Pearson: Upper Saddle River, NJ, USA, 2010.

69. Fan, X.; Sivo, S.A. Sensitivity of fit indexes to misspecified structural or measurement model components: Rationale of two-index strategy revisited. Struct. Equat. Model. 2005, 12, 343-367. [CrossRef]

70. Hooper, D.; Coughlan, J.; Mullen, M. Structural equation modelling: Guidelines for determining model fit. Electron. J. Bus. Res. Methods 2008, 6, 53-60.

71. Nunnally, J.C.; Bernstein, I. Psychometric Theory (McGraw-Hill Series in Psychology); McGraw-Hill: New York, NY, USA, 1994; Volume 3.

72. Bougheas, S.; Lim, H.; Mateut, S.; Mizen, P.; Yalcin, C. Foreign currency borrowing, exports and firm performance: Evidence from a currency crisis. Eur. J. Financ. 2018. [CrossRef]

73. Chae, H.-C.; Koh, C.E.; Park, K.O. Information technology capability and firm performance: Role of industry. Inf. Manag. 2018, 55, 525-546. [CrossRef]

74. Oehme, M.; Bort, S. SME internationalization modes in the German biotechnology industry: The influence of imitation, network position, and international experience. J. Int. Bus. Stud. 2015, 46, 629-655. [CrossRef]

75. Dolfsma, W.; Van der Eijk, R. Network position and firm performance-the mediating role of innovation. Technol. Anal. Strateg. Manag. 2017, 29, 556-568. [CrossRef] 